\title{
Osteoid osteoma of the olecranon fossa: percutaneous resection guided by CT-Scan
}

\author{
Zied Jlalia*, Khaled Khelil, Helmi Bouker, Moez Ouertatani and Mourad Jenzri \\ Pediatric Orthopedic Department, Kassab Institute for Orthopedic Surgery, Tunisia
}

\begin{abstract}
In spite of the interest carried in the osteoid osteoma and in the large number of publications, intra articular localization remains exceptional, what returns difficult its diagnosis and its treatment. We report a case of osteoid osteoma developed in the olecranon fossa in a young man. The initially diagnosis was a chronic epicondylitis and the patient was sent to us after18 months within limitation of the mobility in flexion extension. The scintigraphy and the scanner allowed the diagnosis and the percutaneous resection guided by CT (computerized tomography), obtain an immediate disappearance of pain and normal function of the elbow. The anatomopathologic study confirmed the diagnosis. Through this observation, we discuss the modalities as well as the diagnostic and therapeutic difficulties put by the intra-articular osteoid osteoma by explaining the advantages of the CT guided percutaneous resection.
\end{abstract}

\section{Introduction}

Osteoid osteoma is a benign Tumor that affects the young adult population, it occurs in the shafts of long bones. The elbow is a rare location and the intra-articular site is exceptional causing many diagnostic and therapeutic problems. This case is about an osteoid osteoma of the large sigmoid cavity of the ulna treated by percutaneous resection.

\section{Case report}

Mr Z, 30 years old, right handed consulted for an 18 months history of spontaneously occuring pain in his right elbow. It was inflammatory type, permanent and resistant to analgesic drugs (paracetamol). The pain was located at the outer side of the elbow and was radiating to the dorsal side of the forearm. He has had multiple epicondyle injections without efficiency in pain relief . Clinical examination revealed a sharp pain caused by lateral epicondyle palpation, painful mobility of the elbow with a flessum of $20^{\circ}$, whereas pronosupination was normal . X-rays investigation was normal (Figure 1 and 2), biology and electromyogram (EMG) were abnormal. Ultrasonography of the right elbow showed significant synovial thickening with color doppler hyperhemia associated with intra-articular effusion. Scintigraphy showed diffuse hyperfixation of the elbow. MRI showed significant bone and of soft tissue oedema associated with joint effusion. The CT revealed a calcified nidus of the large sigmoid cavity of the ulna surrounded by a clear border within a poorly limited osteocondensation with intra-articular effusion (Figure 3). The diagnosis of intra-articular osteoid osteoma of the elbow was confirmed and the aspirin test was positive. Because of the difficulty of the surgical approach, percutaneous resection was used under CT guidance. Loco-regional anaesthesia (axillary block) following the classic aseptic rules was done. A guide pin was placed posterolaterally after CT scan and then using a motorized $8 \mathrm{~mm}$ diameter trephine, a block resection of the osteoid osteoma was performed. The CT control confirmed the complete resection of the nidus (Figure 4). A postoperative immobilization of seven days has been prescribed. The evolution was marked by a complete and immediate disappearance of the pain and a recovery of the elbow mobility. Histological examination confirmed the diagnosis of osteoid osteoma. Thirteen months after surgery, the elbow was painless, with complete mobility, and radiological control showed the ossification of the resected bone core.
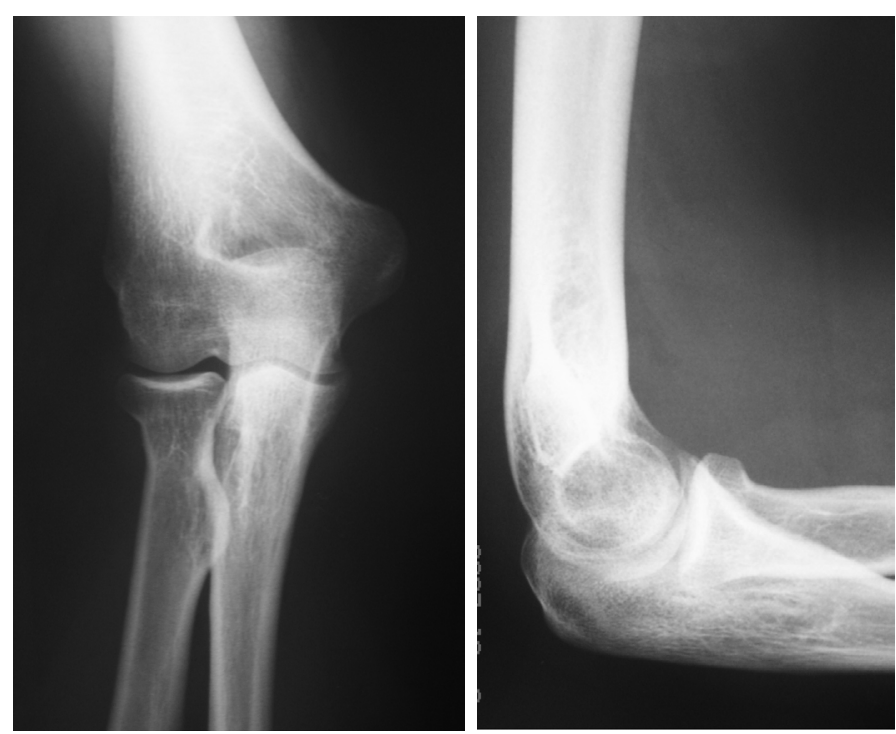

Figure 1 and 2. X-rays investigation of the right elbow

Correspondence to: Zied Jlalia, Pediatric Orthopedic Department, Kassab Institute for Orthopedic Surgery, Ksar said 2010 Tunis, Tunisia, Tel: +00 216 21069395; E-mail : zied_j@yahoo.fr

Key words: osteoid osteoma, elbow, resection

Received: January 03, 2018; Accepted: January 23, 2018; Published: January 26 2018 


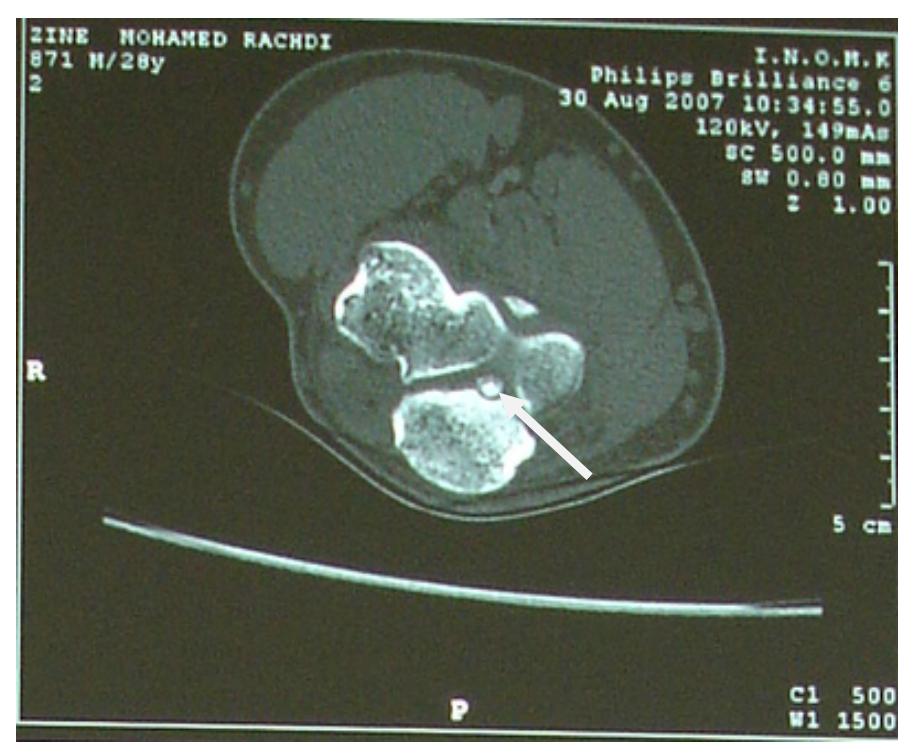

Figure 3. Calcified nidus of the large sigmoid cavity of the ulna surrounded by a clear border

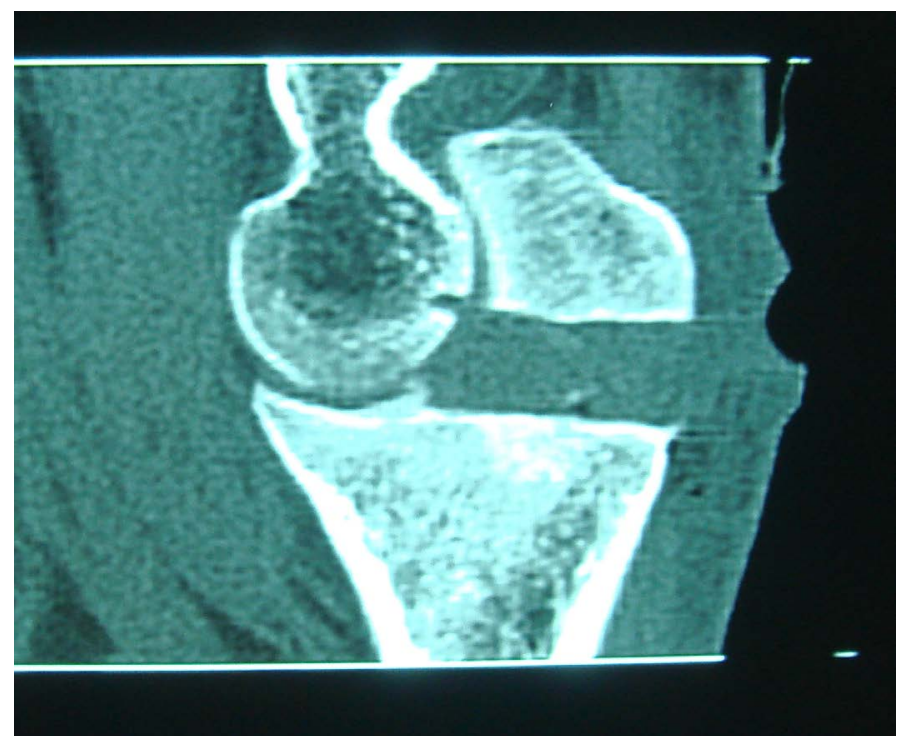

Figure 4. CT control confirmed the complete resection of the nidus

\section{Discussion}

The intra-articular locations of osteoid osteomas of the elbow are exceptional. They have been reported mainly in the olecranon fossa [13] or in the coronoid fossa [4]

Clinical and radiographic diagnosis is often difficult $[3,5,6]$. Pain is the master symptom of affection. Two characters are highly evocative, a nocturnal recrudescence but this character is inconstant [3] and sensitivity to aspirin. Some authors have made a diagnostic test [7-9].

The effectiveness of aspirin, however, is transient and varies widely according to publications from 30 to $100 \%$ of cases $[7,10]$. The particularity of the articular localization of the osteoid osteoma is related to its borrowing symptomatology and to the discretion of its radiographic expression [8,11]. In this localization, osteoid osteoma causes intra and peri-articular manifestations producing a chronic non-specific synovitis [11], mono arthritis [12,13], and epicondylitis or epitrochleitis $[14,15]$. The nidus is not surrounded by reactive osteocondensation and can develop in the articular cavity [2] where it maintains an inflammatory state with hydarthrosis. Prono-supination was normal, but flexion / extension was affected [16]. A diagnostic delay of up to several years is usually observed in the atypical clinical and radiographic picture $[11,17]$. The radiographic stage remains delicate because the nidus is rarely visible. Perilesional osteocondensation, so characteristic of osteoid osteoma, remains minimal or absent in articular localizations and there is often a reactionary joint effusion. Railhac [18] explains the absence of reactive bone condensation in these locations by the differences in function between the intra and extra articular periosteum (this phenomenon is analogous to the lack of bone callus formation in articular fractures).

For cases diagnosed late, there may be joint narrowing and osteophytes, the joint prognosis being compromised by osteoarthritis. The scintigraphy can wrong in the absence of the classic double density image. Indeed the fixation is diffuse and not very intense. In case of associated synovitis, the uptake is diffuse [7]. Some authors [16] advocate the use of magnetic resonance imaging (MRI) in the diagnosis of osteoid osteoma, especially in children and young adults. However, in its intra-articular location, its diagnosis may be more difficult on MRI because of the predominance of inflammatory phenomena and the poor visibility of the nidus. For these intra-articular locations, the scanner remains the essential examination [19]. Many authors [20] consider that the combination scanner scintigraphy is the balance of choice. Several therapeutic modalities are proposed in the literature. Norman [21], Cailleret [22] prefer open resection because it would guarantee a better clinical result with no recurrence. Arthroscopic Intra articular osteoid osteoma resection according to Nourissat [23] and Zupanc [24] would allow more precise and less deleterious excision. Several percutaneous treatment techniques are currently available. Percutaneous resection under scanographic control increasingly responds to the comfort of excising the nidus with fewer complications and has the advantage of being able to obtain histological confirmation. Indeed, it allows a precise identification, a reduced approach, a limited bone sacrifice and a short hospitalization. Kohler [25] has perfectly described this method of resection and others have validated this technique while emphasizing its limits $[26,27]$. The CT scan of the osteoid osteoma is the first step of the intervention, followed by CT guidance of a pin centered in the nidus. A toothed strawberry carries the tumor and the few millimeters of bone that surround it. The immediate TDM control makes it possible to affirm the completeness of the resection [19]. The loss of substance is filled by spontaneous osteogenesis. Histological examination confirms the diagnosis. Other percutaneous CT techniques are of more recent description and consist of coagulation of the nidus by Laser or Radiofrequency [19]. These last two methods are certainly less fragile for the bone, but they require specific equipment and do not allow to obtain a histological confirmation of the nature of the tumor and the completeness of the excision [28].

\section{Conclusion}

Intra articular osteoid osteoma of the elbow is exceptional. This diagnosis should be discussed in the presence of a chronic resistant pain. The aspirin test is interesting in this case The CT remains the gold-standard investigation. Percutaneous CT resection is very useful.

\section{References}

1. Sherman MS (1947) Osteoid osteoma associated with changes in adjacent joint ; report of two cases. J Bone Joint Surg Am 29: 483-490 [Crossref]

2. Simon L, Claustre J, Picard JJ, Marty M, Blotman F (1972) Intra-articular osteoid osteoma of the elbow Rhumatologie 24: 377-382 [Crossref] 
3. Marcove RC, Freiberger RH (1966) Osteoid osteoma of the elbow--a diagnostic problem. Report of four cases. J Bone Joint Surg Am 48: 1185-1190 [Crossref]

4. Shifrin LZ, Reynolds WA (1971) Intra-articular osteoid osteoma of the elbow. A case report. Clin Orthop Relat Res 81: 126-129 [Crossref]

5. Contreras A, Isasi C, Silveira J, Barbadillo C, Mulero J, et al. (2000) Intraarticular osteoid osteoma. J Rheumatol 27: 1560-1561 [Crossref]

6. Weber KL, Morrey BF (1999) Osteoid osteoma of the elbow: a diagnostic challenge. $J$ Bone Joint Surg Am 81: 1111-1119 [Crossref]

7. Freiberger RH, Loitman BS, Helpern M, Thompson TC (1959) Osteoid osteoma; report on 80 cases. Am J Roentgenol Radium Ther Nucl Med 82: 194-205 [Crossref]

8. Sherman MS (1947) Osteoid osteoma; review of the literature and report of 30 cases. $J$ Bone Joint Surg Am 29: 918-930 [Crossref]

9. Cohen MD, Harrington TM, Ginsburg WW (1983) Osteoid osteoma: 95 cases and a review of the literature. Semin Arthritis Rheum 12: 265-281 [Crossref]

10. Debeyre J, Kenesi C, Goutallier D, Bartoletti R (1975) Osteoid osteoma. Chirurgie 101: 913-919 [Crossref]

11. Corbett JM, Wilde AH, McCormack LJ, Evarts CM (1974) Intra-articular osteoid osteoma; a diagnostic problem. Clin Orthop Relat Res : 225-230 [Crossref]

12. García-Vivar ML, Galindez E, Aróstegui J, García Llorente F, Uriarte E, et al. (1996) Chronic monoarthritis caused by osteoid osteoma. An Med Interna 13: 344-346 [Crossref]

13. Weber KL, Morrey BF (1999) Osteoid osteoma of the elbow: a diagnostic challenge. $J$ Bone Joint Surg Am 81: 1111-1119. [Crossref]

14. Higgins T, Kelly M, Curtin J (2002) Osteoid osteoma of the distal humerus mimicking tennis elbow. Ir Med J. 95: 248-249.

15. Pascarel B, Zipoli J.L. Honton (1993) Ostéome ostéoïde de la petite cavité sigmoïde du cubitus. Revue de chirurgie orthopédique 79: 306-308.

16. Ralph C, Marcov and Robert Freiberg (1966) Osteoid osteoma of the elbowAdiagnostic problem. Report of four cases. J Bone Joint Surg AM 48: 1185-1190.
17. Golding JS (1954) The natural history of osteoid osteoma; with a report of twenty cases. J Bone Joint Surg Br 36B: 218-29 [Crossref]

18. Raihac JJ, Bonne Vialle P, Clairotte M, Galyfourlade D. Imagerie des tumeurs osseuses. sauramps médical, montpellier 152-171

19. Assoun J, Railhac JJ, Bonnevialle P, Poey C, Salles de Gauzy J, et al., (1993) Osteoid osteoma: percutaneous resection with CT guidance. Radiology 188: 541-547 [Crossref]

20. Helms CA, Hattner RS, Vogler JB (1984) Osteoid osteoma: radionuclide diagnosis. Radiology 151: 779-784 [Crossref]

21. Norman A, Abdelwahab IF, Buyon J Matzkin E (1986) Osteoid osteoma of the hip stimulating an early onset of osteo arthritis. Radiology 158: 417-420.

22. Caillieret J, Fontaine C, Ducloux M, Letendart J, Duquennoy A (1986) Osteoid osteoma of the upper extremity of the femur. Rev Chir Orthop Reparatrice Appar Mot 72: 101-103 [Crossref]

23. Nourissat G, Kakuda C, Dumontier C (2007) Arthroscopic excision of osteoid osteoma of the elbow. Arthroscopy 23: 799 [Crossref]

24. Yoshida T, Gotoh M, Hirai Y, Shinozaki T, Higuchi F (2006) Monoarthritis of the elbow caused by intraarticular osteoid osteoma. J Rheumatol 33: 196-197. [Crossref]

25. Kohler R, Rubini J, Postec F, Canterino I, Archimbaud F (1995) Traitement de l'ostéome ostéoïde par forage-résection percutané sous contrôle tomodensitométrique. À propos de 27 cas. Rev Chir Orthop 81: 317-325.

26. Donahue F, Ahmad A, Mnaymneh W, Pevsner NH (1999) Osteoid osteoma. Computed tomography guided percutaneous excision. Clin Orthop Relat Res 191-196 [Crossref]

27. Voto SJ, Cook AJ, Arrington G, Weiner DS, Ewing JW (1990) Treatment of osteoid osteoma by computed tomography guided excision in a pediatric patient. $J$ Pediatr Orthop 10: 510-513

28. Zupanc O, Sarabon N, Strazar K (2007) Arthroscopic removal of juxtaarticular osteoid osteoma of the elbow. Knee Surg Sports Traumatol Arthrosc 15: 1240-1243. [Crossref]

Copyright: (C2018 Jlalia Z. This is an open-access article distributed under the terms of the Creative Commons Attribution License, which permits unrestricted use, distribution, and reproduction in any medium, provided the original author and source are credited. 